\title{
CARDIOVASCULAR SIGNS OF ACUTE HYPOXAEMIA AND HYPERCARBIA DURING ENFLURANE AND HALOTHANE ANAESTHESIA IN MAN
}

\author{
P. MaNNINEN AND R.L. KNILL
}

HYPOXIA AND HYPERCARBIA are always potential complications of anaesthesia. How can they be recognized quickly? Signs frequently sought in the anaesthetized patient are changes in heart rate and rhythm and blood pressure. In awake man, acute hypoxaemia accelerates heart rate obviously, while increasing blood pressure only slightly ${ }^{1.2}$; acute hypercarbia augments both..$^{3.4}$ The cardiovascular responses to steady states of hypercarbia during anaesthesia have been previously described d.6 $^{5}$ and are well known; however, there is no information on the human response to hypoxia during anaesthesia.

We have studied changes in heart rate and blood pressure brought about by brief periods of controlled hypoxaemia $\left(\mathrm{PO}_{2}\right.$ approximately $6.0 \mathrm{kPa}$ [45 torr]) in human subjects awake and when anaesthetized with enflurane or halothane. We have also recorded their responses to a mild carbon dioxide stimulus $\left(\mathrm{PCO}_{2}\right.$ increment of $1.3 \mathrm{kPa}$ [ 10 torr] $]$. Our results indicate that during anaesthesia with these drugs, neither blood pressure nor heart rate is a reliable indicator of acute moderate hypoxaemia or of mild hypercarbia.

\section{Methods}

We studied 13 young healthy subjects. Their mean age, weight and height ( $\pm S$.D.) were respectively $22 \pm 5$ years, $66 \pm 14 \mathrm{~kg}$ and $170 \pm 9$ centimetres. All were patients scheduled for elective dental surgical procedures, usually multiple odontectomy. Each was informed of the protocol and risks involved and signed a written consent form which had been approved by the University Human Research Committee. We

P. Manninen, M.D., Resident; R.L. Knill, M.D. F.R.C.P.(C), Assistant Professor. Department of Anaesthesia, University Hospital, University of Western Ontario, London, Canada.

This work was supported by the Medical Research Council of Canada, Development Grant 150 and a grant from Ohio Medical Products. It was presented in part at the Canadian Anaesthetists* Society Meeting in Ottawa, Ontario, June 1978.

Address reprint requests to Dr. R.L. Knill, Department of Anaesthesia, P.O. Box 5339, Postal Stn. A London, Ontario, Canada, N6A SA5.

Canad. Anaesth. Soc. J., vol. 26, no. 4, July 1979 studied each subject twice, first while anaesthetized with either enflurane $(n=8)$ or halothane $(n=5)$ and subsequently while conscious.

Anaesthesia studies were conducted during a 45-minute period of anaesthesia before the operation. The subjects were not premedicated. We induced anaesthesia with thiopentone 3 to $5 \mathrm{mg} \cdot \mathrm{kg}^{-1}$ and, after producing neuromuscular paralysis with succinylcholine $I \mathrm{mg} \cdot \mathrm{kg}^{-1}$ we intubated the trachea with an 8 or $9 \mathrm{~mm}$ cuffed tube. The subject inhaled a mixture of oxygen and either enflurane or halothane from a nonrebreathing circuit for a period of at least $30 \mathrm{~min}$ utes. The concentration of inspired vapour was set to achieve a steady end-tidal concentration equivalent to I.1 MAC. Intravenous fluid (5 per cent dextrose in 0.2 per cent saline) was infused in amounts up to one litre to maintain systolic blood pressure above 70 per cent of the awake value. Nasopharyngeal temperature was monitored and remained above 36 degrees Celsius in all subjects. When the end-tidal vapour concentration had been steady for ten minutes, we induced periods of hypoxaemia and hypercarbia individually and recorded heart rate and blood pressure responses.

We conducted conscious studies in a quiet laboratory approximately one week after the operation. Each subject sat in a comfortable chair breathing through a mouthpiece with a nose-clip in place. We induced hypoxaemia and hypercarbia by the same methods employed during anaesthesia and recorded the responses for comparison.

Hypoxaemia in both states was generated with an open circuit. The subject initially inhaled 95 to 100 per cent oxygen for approximately five minutes. With heart rate, blood pressure and endtidal $\mathrm{PCO}_{2}$ stable, air and then nitrogen were gradually added to the inspired gas so that inhaled and end-tidal oxygen tensions fell, the latter to approximately $6.0 \mathrm{kPa}$ (45 torr). With this method, hypoxaemia evolved progressively over five to ten minutes and in the end produced visible cyanosis. We maintained the lowest level of $\mathrm{PO}_{2}$ for 15 to 30 seconds. Carbon dioxide was added to inspired gas as necessary to maintain end-tidal 
TABLE I

Hypoxia Studies

HeART RATE (beats per minute)

\begin{tabular}{cccccc}
\hline \hline \multicolumn{2}{c}{ State } & Hyperoxia & Normoxia & Hypoxia & $\begin{array}{c}\text { Hyperoxic- } \\
\text { hypoxic } \\
\text { difference }\end{array}$ \\
\hline $\begin{array}{c}\text { Enflurane } \\
(\mathrm{n}=8)\end{array}$ & Awake & $74 \pm 6$ & $78 \pm 7$ & $91 \pm 6$ & 17 \\
Halothane & Awake & $81 \pm 5$ & $82 \pm 6$ & $106 \pm 8$ & $8^{*}$ \\
$(\mathrm{n}=5)$ & Anaes. & $68 \pm 3$ & $68 \pm 3$ & $81 \pm 5$ & $13^{*}$ \\
& & $77 \pm 3$ & $78 \pm 3$ & $85 \pm 3$ & \\
Enfiurane & Awake & $85 \pm 3$ & $84 \pm 3$ & $87 \pm 2$ & 2 \\
(n=8) & Anaes. & $62 \pm 3$ & $61 \pm 3$ & $62 \pm 3$ & 0 \\
Halothane & Awake & $85 \pm 7$ & $85 \pm 7$ & $89 \pm 5$ & 4 \\
(n=5) & Anacs. & $62 \pm 3$ & $62 \pm 3$ & $61 \pm 3$ & $-1^{*}$ \\
\hline
\end{tabular}

Reported values are means \pm standard errors of mean.

*Indicates significant difference from awake (p. $<0.01$ ).

isocapnia. After completing this test and before proceeding with the next, we again gave subjects 95 to 100 per cent oxygen to inhale for at least five minutes and ensured that cardiovascular variables and end-tidal $\mathrm{PCO}_{2}$ were steady.

Hypercarbia was induced by the Read rebreathing technique. ${ }^{7} A$ closed circuit with an internal volume of 7 to 10 litres was filled with 7 to 8 per cent carbone dioxide in oxygen. The subject exchanged three large breaths with this circuit (employing positive pressure during anaesthesia) and then ventilated as he would normally while continuing to rebreathe from it. The experiment progressed until the end-tidal carbon dioxide tension had increased 1.3 to $1.6 \mathrm{kPa}$ ( 10 to 12 torr),

During tests of anaesthetized subjects, we maintained anaesthetic levels constant by adding appropriate concentrations of anaesthetic vapour to each testing circuit.

In all studies, exhaled gas was continuously sampled and analyzed immediately by a mass spectrometer (Perkin-Elmer \# 1100), which displayed end-tidal plateau concentrations of oxygen, nitrogen, carbon dioxide and enflurane or halothane. (The instrument was regularly calibrated with Canadian Liquid Air or Scott specialty gases.) During each test, heart rate and rhythm were contintously monitored and recorded by a standard lead II electrocardiogram. Blood pressure was measured two to four times a minute by an automatic Arteriosonde. All variables were inscribed on a time-based multiplechannel recorder.

Electrocardiographic tracings of each test period were examined for the occurrence of ar- rhythmias. Individual values of heart rate were the average of at least 15 seconds of recorded electrocardiogram. Paired values of systolic and diastolic pressure were reduced to mean pressure (i.e. diastolic plus one-third of systolic-diastolic difference) to facilitate comparisons. To analyse each hypoxic test, values of heart rate and mean pressure were determined for conditions of hyperoxia, normoxia and hypoxia (i.e. PETuz of approximately $53.2,13.3$ and $6.0 \mathrm{kPa}(400,100$ and 45 Torr). We considered responses to be simply hyperoxic-hypoxic differences. For anal$y$ sis of carbon dioxide tests, the same values were taken prior to, at the start of and at the terminalion of rebreathing; responses were the differences between values prior to and at the end of rebreathing.

We employed the Student's t-test for individually paired data to evaluate possible differences between conscious and anaesthetic responses.

\section{RESULTS}

There were no unexpected complications of these studies. In the awake state, hypoxaemia and hypercarbia produced the usual subjective sensations, all of which were mild and transient. Anaesthesia without stimuli resulted in modest reductions of mean pressure and small increases in heart rate with enflurane and decreases in heart rate with halothane (Tables I and II). During hypoxaemic and hypercarbic challenges, in both states, the only variables observed to change were heart rate and blood pressure. Arrhythmias were never observed. 
TABLE II

Hypercarba Studies

Heart Rate (beats per minute)

\begin{tabular}{cccccc}
\hline & & & \multicolumn{2}{c}{ Rebreathing } & $\begin{array}{c}\text { Resting- } \\
\text { State }\end{array}$ \\
\cline { 5 - 6 } & Resting & Initial & Terminal & $\begin{array}{c}\text { terminal } \\
\text { difference }\end{array}$ \\
\hline $\begin{array}{c}\text { Enflurane } \\
(\mathrm{n}=8)\end{array}$ & Awake & $78 \pm 4$ & $81 \pm 4$ & $90 \pm 4$ & 12 \\
Halothane & Awake & $82 \pm 2$ & $79 \pm 3$ & $79 \pm 3$ & $-3^{*}$ \\
$(\mathrm{n}=5)$ & Anaes. & $76 \pm 4$ & $79 \pm 4$ & $86 \pm 4$ & 10 \\
& & $72 \pm 3$ & $72 \pm 2$ & $0^{*}$ \\
Enflurane & Awake & $80 \pm 4$ & $80 \pm 4$ & $89 \pm 3$ & \\
$(\mathrm{n}=8)$ & Anaes. & $66 \pm 2$ & $66 \pm 3$ & $65 \pm 3$ & $-1^{*}$ \\
Halothane & Awake & $81 \pm 6$ & $81 \pm 6$ & $92 \pm 5$ & 11 \\
$(\mathrm{n}=5)$ & Anaes. & $65 \pm 3$ & $65 \pm 2$ & $69 \pm 2$ & $4^{*}$ \\
\hline
\end{tabular}

Reported values are means \pm standard errors of mean.

-Indicates significant difference from awake $(p .<0.01)$.
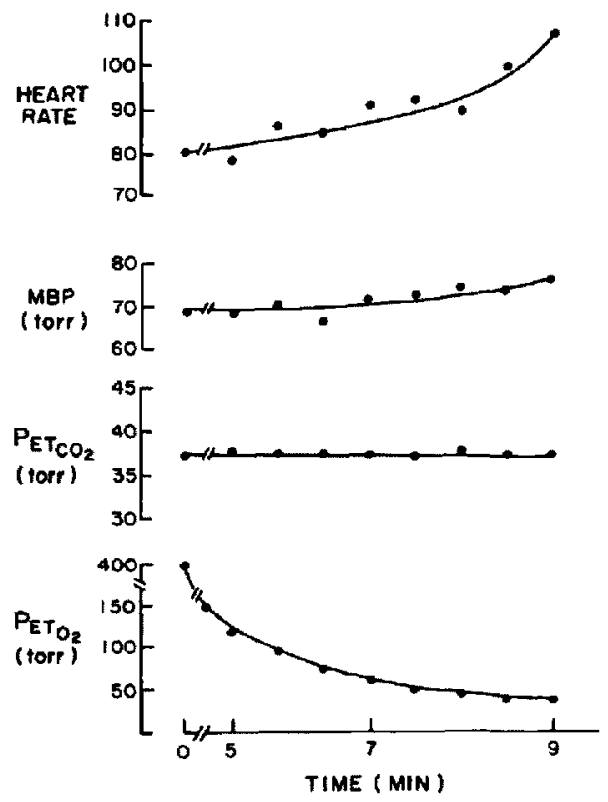

FIgURE I Typical response to hypoxaemia in an awake subject. As end-tidal $\mathrm{PO}_{2}\left(\mathrm{PET}_{\mathrm{O}_{2}}\right)$ fell with time, end-tidal $\mathrm{PCO}_{3}\left(\mathrm{PeT}_{\mathrm{CO}_{2}}\right.$ ) was maintained constant (by addition of $\mathrm{CO}_{2}$ to offset hypocapnic effect of hyperpnea). Responses of heart rate (per minute) and mein blood pressure (MBP, torr) are shown.

A typical response to isocapnic hypoxaemia in a conscious subject is shown in Figure 1 . Hypoxaemia (i.e. $\mathrm{PET}_{\mathrm{O}_{2}} 6.0 \mathrm{kPa}$ [45 torr]) in this state increased heart rate approximately 20 beats per minute and augmented mean blood pressure only slightly. Enflurane and halothane always reduced the heart rate response (Table I) and in three subjects virtually abolished it. Blood pressure did not respond to hypoxaemia during anaesthesia (Table I).

Rebreathing $\left(\mathrm{PCO}_{2}\right.$ increment of $1.3-1.6 \mathrm{kPa}$ [10-12 torr] $]$ in awake subjects increased mean heart rate 11 beats per minute and mean blood pressure $1.3 \mathrm{kPa}$ (10 torr) reflecting increases in both systolic and diastolic pressures (Table II). During anaesthesia resting end-tidal $\mathrm{PCO}_{2}$ was higher than the awake value (0.4-1.2 $\mathrm{kPa}[3-15$ torr]), but the change in $\mathrm{PCO}_{2}$ associated with rebreathing was the same. Enflurane and halothane abolished the heart rate response to this carbon dioxide stimulus and markedly depressed the blood pressure change (Table II).

\section{Discussion}

In awake man, moderate hypoxaemia $\left(\mathrm{Pa}_{\mathrm{a}_{2}}\right.$ $5.3 \mathrm{kPa}$ [40 torr]) impairs the central nervous system, producing disorientation, agitation and decreased visual acuity. Ventilatory and cardiovascular systems are stimulated; there is hyperpnoea, tachycardia and mild hypertension. ${ }^{1,2}$ Cyanosis appears in mucous membranes and skin if haemoglobin saturation falls to $70-80$ per cent.

How do enflurane and halothane anaesthesia modify these clinical expressions of hypoxaemia? They obviously eliminate central nervous system symptoms and signs and recent work suggests that halothane abolishes the ven- 
tilatory sign as well. ${ }^{8}$ In the present study, we have examined the basic circulatory signs of heart rate and rhythm and blood pressure.

We created progressive hypoxaemia by gradually reducing the concentration of oxygen in inspired gas. We monitored end-tidal $\mathrm{Po}_{2}$ throughout each test, terminating the experiment after achieving a $\mathrm{PET}_{\mathrm{O}_{2}}$ of $6.0 \mathrm{kPa}$ (45 torr). It is recognized that the monitored stimulus $\left(\mathrm{PEr}_{\mathrm{O}_{2}}\right.$ ) relates very roughly to hypoxaemia $\left(\mathrm{Pa}_{\mathrm{O}_{2}}\right)$, which in turn is only an approximate guide to the tissue $\mathrm{Po}_{2}$ at various sites which is the actual stimulus. ${ }^{2}$ Furthermore, it is probable that these $\mathrm{Po}_{2}$ relationships differ between awake and anaesthetized states. With normal oxygen tensions in both awake and anaesthetized man, values of end-tidal $\mathrm{PO}_{2}$ are substantially greater than arterial and tissue $\mathrm{PO}_{2}$, but as oxygen tension falls these differences lessen, so that below $\mathrm{Pa}_{\mathrm{CO}_{2}} 9.3 \mathrm{kPa}$ (70 torr), which are the oxygen levels of interest, the end-tidal to arterial gradient is usually less than $0.8 \mathrm{kPa}$ (6 torr) ${ }^{8.9}$ Thus our monitored stimulus was a reasonable index at least of the existence of hypoxaemia in both awake-and anaesthetized states.

The variables we measured were simply heart rate and rhythm and systemic blood pressure. The methods of measurement (the electrocardiograph and a standard inflatable blood pressure cuff) are those commonly employed in clinical practice. For objectivity, systolic and diastolic pressures were detected and recorded automatically by an Arteriosonde, the sensor of which responds to Doppler shifts of transmitted ultrasound.

In agreement with previous studies, we found that hypoxaemia in the conscious state increased heart rate unmistakably, while raising mean blood pressure only slightly. 2,10 Changes in both variables related to $\mathrm{PO}_{2}$ in a non-linear fashion. There were small increases in rate and pressure down to $\mathrm{PO}_{2}$ of $9.3 \mathrm{kPa}$ (70 torr) and then progressively greater increments at lower $\mathrm{PO}_{2}$ (Figure 1). Steady states of enflurane and halothane 1.1 MAC abolished the blood pressure response and reduced the heart rate effect variably (Table 1). During anaesthesia, a few subjects bad virtually no heart rate response to hypoxaemia; in several others, the response was less than 10 beats per minute. Thus, in contrast to the conscious state, the changes in rate during anaesthesia were not reliably of a magnitude which would arouse clinical suspicion. Our level of hypoxaemia did not produce arrhythmias in either state.
While halothane 1.1 MAC clearly diminished the circulatory response to hypoxaemia, at least with respect to heart rate and blood pressure, this effect was comparatively less than the depression of the hypoxic ventilatory reflex previously studied. Halothane nearly always abolished the ventilatory response and frequently even reversed it (i.e. ventilatory depression during hypoxaemia). ${ }^{3}$ The divergent sensitivities of circulatory and ventilatory responses to hypoxaemia was most obvious at sub-anaesthetic doses of halothane (0.05 MAC and 0.1 MAC) which reduced the ventilatory reflex to less than one-half of control," but only marginally interfered with heart rate and blood pressure responses. ${ }^{*}$ It is impossible to explain these effects or differences in effect, as we know little about the site or mechanism of action of halothane on the regulation of circulation and ventilation during hypoxaemia. Data from anaesthetized dogs strongly suggests that the mechanisms of cardiovascular stimulation are closely dependent upon mechanisms related to the associated hyperpnoea, so that abolition of the latter should eliminate the former. ${ }^{12}$ However, our data obtained during sedation and anaesthesia does not support such a linkage in man. Of possible relevance is indirect evidence from a previous human study, ${ }^{8}$ which points out that halothane may have a very potent depressive action on either peripheral chemoreceptors or their immediate central neural connections, which are essential components of the hypoxic ventilatory reflex but apparently of little consequence in mediating the normal cardiac response to hy poxaemia. ${ }^{113}$

To our knowledge, all previous studies of the influence of anaesthesia on hypoxic responses of the systemic circulation have employed animal models. Many which were conducted during ether, cyclopropane and intravenous barbiturate anaesthesia (reviewed by Korner in 1959') suggest that increases of heart rate and blood pressure effected by hypoxaemia during anaesthesia are of a magnitude similar to those observed in the unanaesthetized state. However, data varied widely within and between these studies and no study compared awake and anaesthetic responses in the same animals directly. Recent investigations of hypoxaemia in dogs anaesthetized with halothane, trichlorethylene and methoxyflurane indicate that circulatory responses to hypoxaemia are sometimes reduced by these drugs when they are given at moderate anaesthe.

*Manninen, P.H. Unpublished observations. 
tic dosages and suggest that blood pressure and heart rate signs may be clinically unreliable. ${ }^{14-16}$ However, once again interpretation of these studies is made difficult by the fact that there were no conscious controls. In any case, the relevance of animal data to human must be questioned, as there appears to be considerable species specificity in circulatory responses to hypoxaemia in both awake and anaesthetic states. ${ }^{1.2}$

Our results for hypoxaemic responses should be interpreted with care, noting that we have studied only conditions of brief hypoxaemia in healthy young subjects breathing spontaneously during steady states of anaesthesia without surgical stimulation. We stress that we tested responses to acute and brief hypoxaemia; although the maximum and sustained heart rate response in awake man is evident during the first few moments of low $\mathrm{Po}_{2},{ }^{17}$ lengthier periods of hypoxaemia could conceivably have produced different anaesthetic results. The stimulus of surgery is well known to alter cardiovascular function; whether it also modifies responses to hypoxaemia remains to be seen. In anaesthetized dogs, the mode of ventilation, i.e., spontaneous or positive pressure, frequently determines the qualitative nature of hypoxic circulatory responses; for example, tachycardia may occur with spontaneous breathing and bradycardia with intermittent positive pressure ventilation. ${ }^{12,18}$ Whether this ventilatory factor has any importance in anaesthetized man is not known.

The level of hypoxaemia which we tested, although only moderate, is one which ideally should be detectable in clinical practice. Our experience suggests that, during enflurane or halothane anaesthesia, the first reliable sign is cyanosis of the lips and mucous membranes: (with a surgical incision, there may also be discolouration of the surgical field). Due to the variable relationship of cyanosis to hypoxaemia, dependent upon local blood flow, haemoglobin and tissue pigments, the detection of hypoxaemia by the appearance of cyanosis may sometimes required $\mathrm{PO}_{2}$ levels close to those causing tissue damage. The safety of anaesthesia would no doubt be improved by a more sensitive and reliable method of diagnosing acute hypoxaemia.

Hypercarbia in conscious man increases both heart rate and blood pressure, ${ }^{3.4}$ the magnitude of response relating directly to the magnitude of hypercarbia. In addition, increased $\mathrm{PCO}_{2}$ has an arrhythmogenic effect. ventricular arrhythmias being generally the first to appear. ${ }^{19}$ Most general anaesthetics tend to mask the heart rate and blood pressure responses. ${ }^{5.6}$ During cyclopropane and halothane anaesthesia, in particular. the arrhythmogenic effect is enhanced. We measured circulatory responses to a $\mathrm{PCO}_{2}$ increment of $1.3-1.6 \mathrm{kPa}(10-12$ torr) created by total rebreathing in a hyperoxic environment. Our technique increased the carbon dioxide level progressively, with the measured change in circuit $\mathrm{PCO}_{2}$ probably refiecting the change in tissue $\mathrm{PCO}_{2} \cdot{ }^{20} \mathrm{In}$ the awake state, responses of heart rate and mean pressure were similar to those previously reported. ${ }^{3}$ Light enflurane and halothane anaesthesia abolished both rate and pressure responses and arrhythmias were never observed (Table II). These data support other studies of anaesthetized man, where reliable circulatory responses required $\mathrm{PCO}_{2}$ increments of $2.0 \mathrm{kPa}$ (15 torr) or more. ${ }^{4.6}$ We emphasize that these results probably relate only to the conditions specified. Preliminary work in our laboratory comparing responses during anaesthesia with and without concurrent surgical stimulation indicate that the factor of surgery may greatly modify rate and rhythm responses to carbon dioxide.

\section{SUMMARY}

We investigated the impact of enflurane and halothane ( $1.1 \mathrm{MAC}$ ) on heart rate and blood pressure responses to experimental hypoxaemia $\left(\mathrm{PET}_{\mathrm{O}_{2}} 6.0 \mathrm{kPa}\right.$ [45 torr]) and small increments in $\mathrm{PCO}_{2}$ (1.3-1.6 kPa [10-12 torr]). The results reaffirm that circulatory signs of mild hypercarbia are virtually abolished by these anaesthetics. The important new observation is that signs of acute moderate hypoxaemia are also markedly depressed. Although potential modifying factors such as surgical stimulation were not evaluated, this study indicates that human subjects anaesthetized with enflurane or halothane lack reliable cardiovascular signs of acute hypoxaemia.

\section{RÉSUMÉ}

Nous avons étudié chez de jeunes volontaires l'influence de l'enflurane et de l'halothane (à 1.1 MAC) sur les réponses circulatoires (fréquence cardiaque et pression artérielle), à l'hypoxémie expérimentale $\left(\mathrm{PO}_{2}\right.$ de fin d'expiration à $6 \mathrm{kPa}(45$ torr) et à de modestes élévations de $\mathrm{PCO}_{2}$ (1.3-1.6 $\mathrm{kPa}[10-12$ torr]). Nos résultats confirment que les signes d'hypercarbie sont virtuellement abolis par les deux agents étudiés. Nous avons pu mettre en évidence l'observation importante que 
les signes d'hypoxie modérée aiguë sont également très atténués. Bien que nous n'ayons pas évalué l'influence de la stimulation chirurgicale, notre étude signale que chez l'humain anesthésié à l'halothane et à l'enflurane, il n'existe pas de signes circulatoires fiables en cas d'hypoxémie aiguë.

\section{ACKNOWLEDGEMENTS}

The authors wish to thank the patients who took part in the study, Miss Jane Clement for technical assistance, the surgeons at University Hospital who co-operated in making time available for testing their patients, and Dr. J. Wade, University of Manitoba, for encouragement and advice.

\section{REFERENCES}

1. KoRNer, P.I. Circulatory adaptations in hypoxia. Physiological Reviews 39: 687 (1959).

2. Kontos, H.A., Levasseur, J.E., Richardson, D.W. Mauck, H.P. \& Patterson, J.L. Comparative circulatory responses to systemic hypoxia in man and in anaesthetized dog. Journal of Applied Physiology 23 (3): 381 ( 1967).

3. CulleN, D.J. \& Eger, E.I. II. Cardiovascular effects of carbon dioxide in man. Anesthesiology 4l: 345 (1974).

4. PrICE, H.L. Effects of carbon dioxide on the cardiovascular system. Anesthesiology 21:652 (1968).

5. Bahlman, S.H., Eger, E.I. II, Halsey, M.J., Stevens, W.C., Shakespeare, T.F., Smith, N.T., Cromwell, T.H. \& Fourcade, H. The cardiovascular effects of halothane in man during spontaneous ventilation. Anesthesiology 36: 494 (1972).

6. Price, H.L., Lurie, A.A., Black, G.W., SechZER, P.H., LINDE, H.W. \& PRICE, M.L. Modification by general anaesthetics (cyclopropane and halothane) of circulatory and sympathoadrenal responses to respiratory acidosis. Annals of Surgery 152: 1071 (1960).

7. READ, D.J.C. A clinical method for assessing the ventilatory response to $\mathrm{CO}_{2}$. Australasian Ann. Med. 16: 20 (1967).
8. KNILL, R.L. \& GELB, A.W. Ventilatory responses to hypoxia and hypercarbia during halothane sedation and anaesthesia in man. Anesthesiology 49: 244 (1978).

9. Weil, T.V., Byrne-Quinn, E. \& Sodal, W. Hypoxic ventilatory drive in normal man. Journal of Clinical Invest. 49: 1061 (1970).

10. Dripps, K.D. \& Comroe, J.H.L. The effect of the inhalation of high and low oxygen concentrations on respiration, pulse rate, ballistocardiogram and arterial oxygen saturation (oximeter) of normal individuals. The American Journal of Physiology 149: 277 (1947).

11. Gely, A.W. \& KNILL, R.L. Subanaesthetic halothane: its effect on regulation of ventilation and relevance to the recovery room. Canad. Anaesth. Soc. J. 25: 488 (1978).

12. Kontos, H.A., Mauck, H.P., Richardson, D.W. \& PATterson, J.L. Mechanism of circulatory responses to systemic hypoxia in the anaesthetized dog. American Journal of Physiology 209 (2): 397 (1965).

13. KRASNEY, J.A. \& KOEHLER, R.C. Influence of arterial hypoxia on cardiac and coronary dynamics in the conscious sinoaortic-denervated dog. Journal of Applied Physiology 43 (6): 1012 (1977).

14. Cullen, D.J. \& EGER, E.I. II. The effects of halothane on respiratory and cardiovascular responses to hypoxia in dogs. Anesthesialogy 33: 487 (1970).

15. Nisbet, H.I.A., Gray, l.G. Olley, P.M. \& JOHnston, A.E. Cardiovascular and respiratory responses to severe hypoxemia during anaesthesia. Canad. Anaesth. Soc. J. 19:339(1972).

16. Gray, I.G., Nisbet, H.I.A., Olley, P.M., Welsh, B.E. Johnston, A.E. Cardiovascular and respiratory responses to severe hypoxemia under anaesthesia. Canad. Anaesth. Soc. J. 20:637 (1973).

17. RAHN, H. \& OTIs, A.B. Alveolar air during simulated fights to high altitudes. American Journal of Physiology 150: 202 (1947).

18. JoNES, J.R., SANdhu, R.S. \& ADWERS, J.R. Acute hypoxia: tachycardia or bradycardia? Circulation 32 (suppl. 2): 120 (1965).

19. BiRT, C. \& COLE, P. Some physiological effects of closed circuit halothane anaesthesia. Anaesthesia 20: 258 (1965).

20. Read, D.J.C. \& Lejeh, J. Blood-brain tissue $\mathrm{PCO}_{2}$ relationships and ventilation during rebreathing. Journal of Applied Physiology 23 (1): 53 (1967). 